\title{
RANCANG BANGUN KULKAS MINI PORTABLE MENGGUNAKAN PELTIER
}

\author{
Aris Suryadi \\ Program Studi Teknik Elektro, Politeknik Enjinering Indorama \\ Kembang Kuning, Jatiluhur, Purwakarta, Jawa Barat 41152 \\ Email: aris.suryadi@pei.ac.id \\ Achmad Firmansyah \\ Program Studi Teknik Elektro, Politeknik Enjinering Indorama \\ Kembang Kuning, Jatiluhur, Purwakarta, Jawa Barat 41152 \\ Email: achmadfirmansyah296@gmail.com
}

\begin{abstract}
ABSTRAK
Pendinginan dengan peltier thermo electric cooler menggunakan modul TEC-12706 untuk mengetahui temperatur yang dicapai pada media dan memberikan inovasi baru dari modul peltier guna mengurangi komponen pada pendinginan konvensial pada umumnya. Dengan memanfaatkan proses kalor pada saat modul peltier dilewati arus maka alat ini akan memindahkan panas dari satu sisi ke sisi lain, biasanya menghasilkan perbedaan panas sekitar $30^{\circ} \mathrm{C}$. Pengujian dilakukan tiga kali, untuk volume air yang berbeda dalam 20 menit pada setiap pengujian hasil rata-rata data yang diperoleh bahwa pada penurunan temperatur, untuk pengujian pertama dengan volume 100 $\mathrm{mL}$ air yaitu $2,3^{\circ} \mathrm{C}$ dan $2,8^{\circ} \mathrm{C}$ pada $200 \mathrm{~mL}$ air dan dengan persentase penurunan suhu mencapai $7,19 \%$ pada 100 $\mathrm{mL}$ air dan $8,93 \%$ volume $200 \mathrm{~mL}$ air.
\end{abstract}

Kata kunci: thermo electric cooler; kalor; pendingin konvensional.

\section{ABSTRACT}

Cooling with a peltier thermo electric cooler uses the TEC-12706 module to determine the temperature achieved in the media and provides new innovations from the peltier module to reduce the components of conventional cooling in general. By utilizing the heat process when the peltier module is passed through the current, this tool will transfer heat from one side to another, usually resulting in a heat difference of around $30^{\circ} \mathrm{C}$. The test is carried out three times, for different volumes of water in 20 minutes on each test the average results of the data obtained are that at a decrease in temperature, for the first test with a volume of $100 \mathrm{~mL}$ of water which is $2.3^{\circ} \mathrm{C}$ and $2.8^{\circ} \mathrm{C}$ at $200 \mathrm{~mL}$ of water and with a percentage decrease in temperature reached $7.19 \%$ in $100 \mathrm{~mL}$ of water and $8.93 \%$ in volume of $200 \mathrm{~mL}$ of water.

Keywords: thermo electric cooler; heat; conventional cooler.

\section{PENDAHULUAN}

Kulkas adalah salah satu fasilitas elektronik pendukung yang digunakan oleh sebagian keluarga dirumah, bahkan hingga super market mengunakan fasilitas pendukung yang satu ini dikarenakan fungsinya yang sangat begitu dibutuhkan untuk menyimpan makanan atau minuman dalam kondisi suhu rendah yang terjaga dengan menurunkan suhu pada objek yang akan didinginkan, oleh karena itu kulkas sangat dibutuhkan sebagai kebutuhan untuk mendinginkan atau menurunkan suhu pada minuman ataupun makanan.[1]

Namun selama ini pada kenyataannya kulkas pada umumnya tidak dapat dibawa kemana saja dikarenakan dimensinya yang cukup besar dan tidak mudah untuk di bawa kemana saja. Oleh karena itu diperlukan suatu modifikasi pada kulkas agar dapat dibawa kemana saja (portable)[1],[2].

Pada perkembangan di jaman sekarang ini kemajuan teknologi berjalan dengan sangat cepat terutama pada alat elektronik, maka kulkas tersebut dikembangkan dengan dimensi ukuran yang dapat secara mudah dibawa kemana-mana (portable) agar kulkas mampu di bawa kemana saja dengan mudah dan untuk memberikan inovasi bagi dunia modern maka penulis terinspirasi dengan pembuatan kulkas mini portable yang dapat dibawa kemana saja [3][4].

\section{METODOLOGI PENELITIAN}

Metodologi penelitian dilakukan dengan pengujian suhu yang sedang berlangsung selama durasi waktu yang ditentukan untuk setiap kenaikan 1 (satu) menit. Kemudian memberikan beban variasi berupa volume air mili liter $(\mathrm{mL})$ dengan variasi setiap $100 \mathrm{~mL}$. Hasil yang didapatkan pada pengukuran suhu 
yang sedang berlangsung beserta suhu yang didapatkan hasil pengukuran disesuaikan dengan hasil perhitungan. Hasil data yang telah ditetapkan pada suhu disaat melakukan proses pengambilan data pada menit yang pertama hingga menit yang berikutnya.

\subsection{Peltier}

Peltier merupakan modul TEC (Thermo Electric Cooler), umumnya dibungkus keramik tipis yang berisikan bismuth telluride di dalamnya [5]. Pada komponen peltier ini jika diberi tegangan 12 VDC maka salah satu sisi akan menjadi dingin dan salah satu sisinya lagi menjadi panas. Peltier ini memiliki 2 sisi, ketika dialiri oleh tegangan DC maka sisi satunya akan menghasilkan panas dan sisi lainnya akan menghasilkan dingin, dapat membuang panas dibagian sisi panasnya sebanyak mungkin maka, sisi lainnya akan menghasilkan dingin yang jauh lebih dingin. Transfer panas dari elemen peltier dapat dilakukan dengan beberapa cara seperti dengan menggunakan kipas dan heatsink. Kemampuan dari sistem pendingin tergantung pada perbedaan temperatur dari kedua sisi elemen, bentuk geometri dan disipasi panas alami [6]. Diperlihatkan pada gambar 1 arah aliran arus pada Peltier.

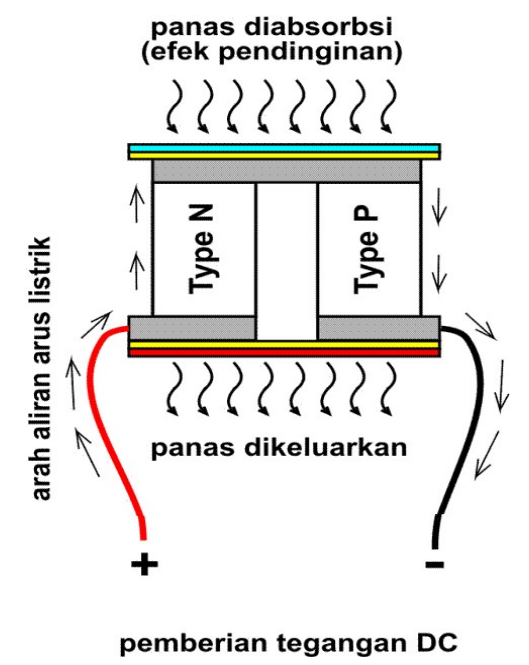

Gambar 1. Arah Aliran Arus Pada Peltier [8]

\subsection{Rancangan Pada Alat}

Rancangan sederhana untuk kulkas mini portable diperlihatkan seperti pada gambar 3.
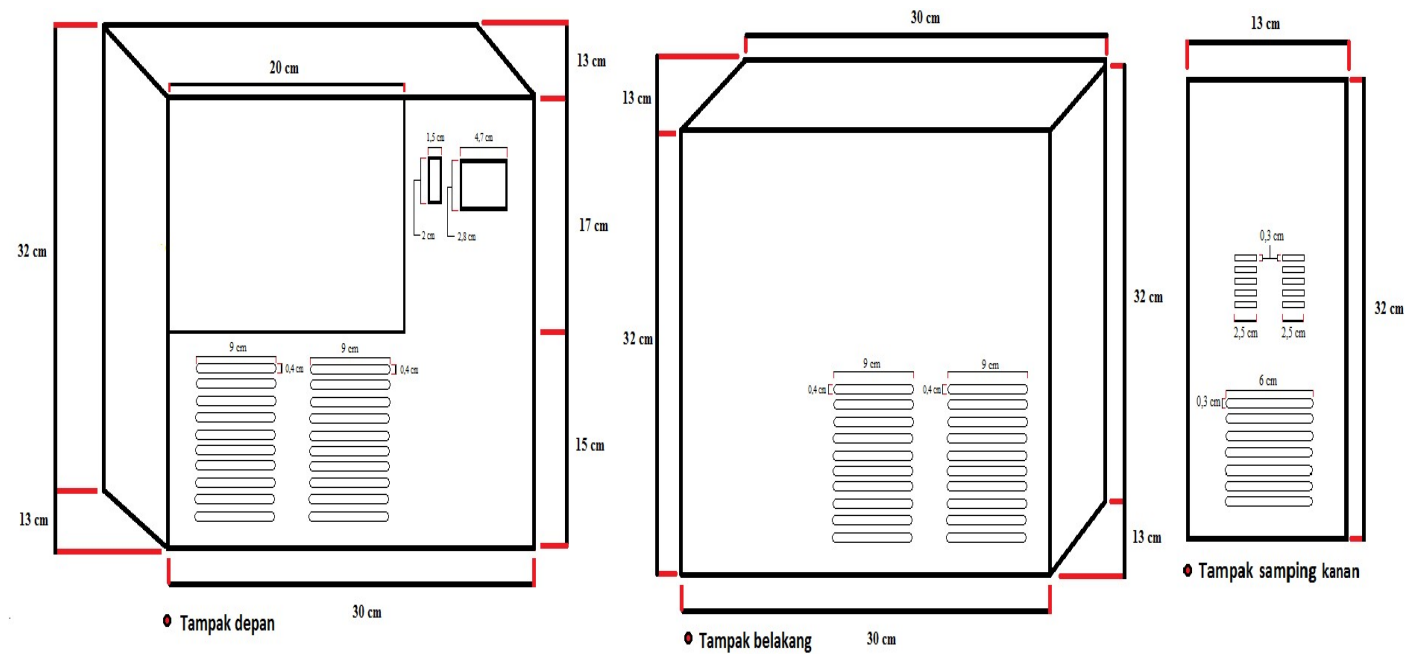

Gambar 3. Rancangan Awal Kulkas Mini 


\section{HASIL DAN PEMBAHASAN}

\subsection{Hasil}

Selanjutnya dilakukan pengujian alat kulkas mini portable ini dengan membandingkan antara proses penurunan suhu dengan perbandingan waktu yang dilakukan untuk memperoleh data perbandingan pada proses perbandingan penurunan temperatur air dalam pengujian terhadap waktu dalam skala volume $100 \mathrm{ml}$ dan $200 \mathrm{ml}$ air dengan pengujian yang dilakukan dalam 3 kali Pengujian.

Adapun bahan yang digunakan pada penelitian ini diantaranya sebagai berikut:

a. Pengujian Pertama

Tabel 1. Hasil pengujian pertama $100 \mathrm{~mL}$ air

\begin{tabular}{|c|c|}
\hline Waktu(Menit) & Termokopel $\left(\right.$ Suhu $\left.{ }^{\circ} \mathrm{C}\right)$ \\
\hline 1 & 26,1 \\
\hline 2 & 25,3 \\
\hline 3 & 24,3 \\
\hline 4 & 23,8 \\
\hline 5 & 23,5 \\
\hline 6 & 23,1 \\
\hline 7 & 22,7 \\
\hline 8 & 22,2 \\
\hline 9 & 21,8 \\
\hline 10 & 21,5 \\
\hline 11 & 21,3 \\
\hline 12 & 21,0 \\
\hline 13 & 20,7 \\
\hline 14 & 20,6 \\
\hline 15 & 20,6 \\
\hline 16 & 20,5 \\
\hline 17 & 20,4 \\
\hline 18 & 20,3 \\
\hline 19 & 20,2 \\
\hline 20 & 20,0 \\
\hline
\end{tabular}

Hasil yang didapat pada Pengujian pertama pada $100 \mathrm{~mL}$ air perubahan suhu yang di dapat yaitu mencapai $6,1^{\circ} \mathrm{C}$ dengan suhu awal pada menit pertama pembacaan termokopel yaitu $26,1^{\circ} \mathrm{C}$ dan penurunan suhu pada pembacaan akhir pengujian termokopel yaitu mencapai $20^{\circ} \mathrm{C}$ pada penurunan suhu yang di pengaruhi oleh beban $100 \mathrm{~mL}$ air di karenakan semakin besar beban yang di dinginkan maka semakin besar pula kalor yang di pindahkan oleh petier. 
Tabel 2. Hasil pengujian pertama pada $200 \mathrm{~mL}$ air

\begin{tabular}{|c|c|}
\hline Waktu (Menit) & Termokopel $\left(\right.$ Suhu $\left.{ }^{\circ} \mathrm{C}\right)$ \\
\hline 1 & 22,1 \\
\hline 2 & 21,4 \\
\hline 3 & 21,3 \\
\hline 4 & 21,2 \\
\hline 5 & 21,1 \\
\hline 6 & 21,0 \\
\hline 7 & 20,9 \\
\hline 8 & 20,8 \\
\hline 9 & 20,5 \\
\hline 10 & 20,3 \\
\hline 11 & 20,1 \\
\hline 12 & 19,9 \\
\hline 13 & 19,8 \\
\hline 14 & 19,3 \\
\hline 15 & 19,0 \\
\hline 16 & 18,8 \\
\hline 17 & 17,8 \\
\hline 18 & 17,7 \\
\hline 19 & 17,5 \\
\hline 20 & 17,3 \\
\hline
\end{tabular}

Hasil yang didapat pada Pengujian pertama pada $200 \mathrm{~mL}$ air perubahan suhu yang di dapat yaitu mencapai $5,8^{\circ} \mathrm{C}$ dengan suhu awal pada menit pertama pembacaan termokopel yaitu $22,1^{\circ} \mathrm{C}$ dan penurunan suhu pada pembacaan akhir pengujian termokopel yaitu mencapai $17,3^{\circ} \mathrm{C}$ pada penurunan suhu yang di pengaruhi oleh beban $200 \mathrm{~mL}$ air di karenakan semakin besar beban yang di dinginkan maka semakin besar pula kalor yang di pindahkan oleh petier. Berikut ini adalah kurva pengujian suhu terhadap waktu pada gambar 4. 


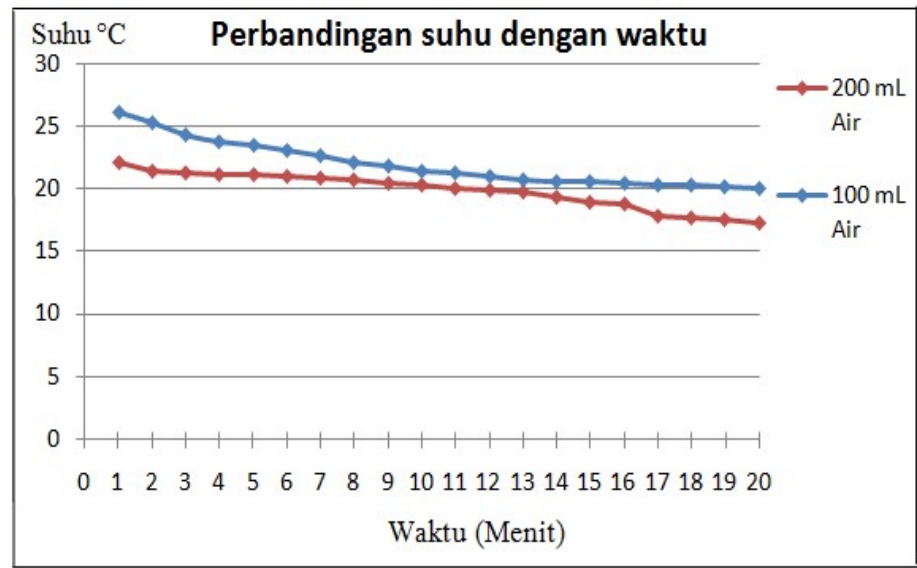

\section{Gambar 4. Kurva Pengujian Pertama Pengujian Suhu Terhadap Waktu}

Pada gambar 4 menunjukan kurva pengujian terhadap lemari pendingin pada volume $100 \mathrm{~mL}$ dan $200 \mathrm{~mL}$ air pada penurunan suhu awal terdapat penurunan selisih suhu $4^{\circ} \mathrm{C}$ yang dipengaruhi oleh beban yang lebih besar yaitu dengan $200 \mathrm{~mL}$ air dan pada menit ke 12 dan menit ke 13 terjadi penunjukan suhu yang hampir sama pada kurva yang di akibatkan oleh terjadinya perubahan suhu pada temperatur udara yang tidak konstan yang dihisap oleh kipas pendingin untuk membantu pembuangan kalor dari sisi panas peltier.

b. Pengujian Kedua

Tabel 3. Hasil pengujian kedua pada $100 \mathrm{~mL}$ air

\begin{tabular}{cc}
\hline Waktu (Menit) & Termokopel (Suhu $\left.{ }^{\circ} \mathbf{C}\right)$ \\
\hline 1 & 23,6 \\
2 & 22,6 \\
3 & 22,3 \\
4 & 22,2 \\
5 & 22,0 \\
6 & 21,9 \\
7 & 21,9 \\
8 & 21,8 \\
9 & 21,8 \\
10 & 21,7 \\
11 & 21,6 \\
12 & 21,5 \\
13 & 21,5 \\
14 & 21,5 \\
15 & 21,4 \\
16 & 21,3 \\
17 & 21,1 \\
18 & 21,1 \\
\hline
\end{tabular}




\begin{tabular}{cc}
\hline Waktu (Menit) & Termokopel (Suhu $\left.^{\circ} \mathbf{C}\right)$ \\
\hline 19 & 21,0 \\
20 & 20,9 \\
\hline
\end{tabular}

Hasil yang didapat pada pengujian kedua pada $100 \mathrm{~mL}$ air perubahan suhu yang didapat yaitu mencapai $2,7^{\circ} \mathrm{C}$ dengan suhu awal pada menit pertama pembacaan termokopel yaitu $23,6^{\circ} \mathrm{C}$ dan penurunan suhu pembacaan akhir pengujian pada termokopel yaitu mencapai $20,9^{\circ} \mathrm{C}$ pada penurunan suhu yang dipengaruhi oleh beban $100 \mathrm{ml}$ air dikarenakan semakin besar beban yang didinginkan maka semakin besar pula kalor yang dipindahkan oleh petier.

Tabel 4. Hasil pengujian kedua pada $200 \mathrm{~mL}$ air

\begin{tabular}{cc}
\hline Waktu (Menit) & Termokopel (Suhu $^{\circ}$ C) \\
\hline 1 & 22,1 \\
2 & 21,6 \\
3 & 21,3 \\
4 & 21,1 \\
5 & 20,8 \\
6 & 20,7 \\
7 & 20,7 \\
8 & 20,5 \\
9 & 20,2 \\
10 & 18,8 \\
11 & 18,4 \\
12 & 18,1 \\
13 & 17,8 \\
14 & 17,9 \\
15 & 17,9 \\
16 & 17,8 \\
17 & 17,7 \\
18 & 16,8 \\
19 & 16,2 \\
20 & 16,1 \\
\hline &
\end{tabular}

Hasil yang didapat pada pengujian kedua pada $200 \mathrm{~mL}$ air perubahan suhu yang didapat yaitu mencapai $6^{\circ} \mathrm{C}$ dengan suhu awal pada menit pertama pembacaan termokopel yaitu $22,1^{\circ} \mathrm{C}$ dan penurunan suhu pada pembacaan akhir pengujian termokopel yaitu mencapai $16,1^{\circ} \mathrm{C}$ pada penurunan suhu yang dipengaruhi oleh beban $200 \mathrm{~mL}$ air dikarenakan semakin besar beban yang didinginkan maka semakin besar pula kalor yang dipindahkan oleh petier.

Berikut ini adalah kurva pengujian suhu terhadap waktu pada gambar 5. 


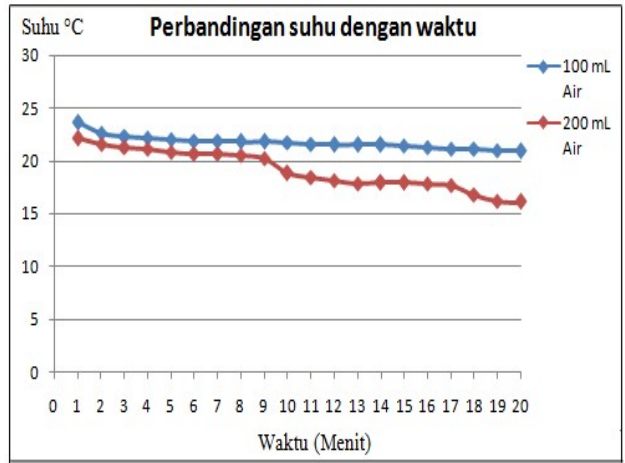

Gambar 5. Kurva Pengujian Suhu Terhadap Waktu

Pada gambar 5 menunjukan kurva pengujian terhadap lemari pendingin pada volume $100 \mathrm{~mL}$ dan $200 \mathrm{~mL}$ air pada penurunan suhu awal terdapat penurunan selisih suhu $1,5^{\circ} \mathrm{C}$ yang dipengaruhi oleh beban yang lebih besar yaitu dengan $200 \mathrm{~mL}$ air dengan penurunan suhu pada menit pertama, pada menit ke 9 dan menit ke 10 terjadi penunjukan suhu tertinggi pada $200 \mathrm{ml}$ air yang dipengaruhi oleh perubahan pada temperatur suhu ruangan yang tidak konstan yang dihisap oleh kipas pendingin untuk membantu pembuangan kalor dari sisi panas peltier.

c. Pengujian Ketiga

Tabel 5. Hasil pengujian ketiga pada $100 \mathrm{~mL}$ air

\begin{tabular}{cc}
\hline Waktu (Menit) & Termokopel (Suhu $\left.{ }^{\circ} \mathbf{C}\right)$ \\
\hline 1 & 17,3 \\
3 & 16,6 \\
4 & 16,3 \\
5 & 16,0 \\
6 & 15,7 \\
7 & 15,4 \\
8 & 15,1 \\
9 & 14,7 \\
10 & 14,3 \\
11 & 14,1 \\
12 & 13,9 \\
13 & 13,7 \\
14 & 13,5 \\
15 & 13,5 \\
16 & 13,3 \\
17 & 13,2 \\
18 & 13,2 \\
19 & 13,3 \\
20 & 13,2 \\
& 13,1 \\
\hline &
\end{tabular}


Hasil yang didapat pada pengujian ketiga pada $100 \mathrm{~mL}$ air perubahan suhu yang didapat yaitu mencapai $4,2^{\circ} \mathrm{C}$ dengan suhu awal pada menit pertama pembacaan termokopel yaitu $17,3^{\circ} \mathrm{C}$ dan penurunan suhu pada pembacaan akhir pengujian termokopel yaitu mencapai $13,1^{\circ} \mathrm{C}$ pada penurunan suhu yang dipengaruhi oleh beban $100 \mathrm{~mL}$ air dikarenakan semakin besar beban yang didinginkan maka semakin besar pula kalor yang dipindahkan oleh petier.

Tabel 6. Hasil pengujian ketiga pada $200 \mathrm{~mL}$ air

\begin{tabular}{|c|c|}
\hline Waktu (Menit) & Termokopel $\left(\right.$ Suhu $\left.{ }^{\circ} \mathrm{C}\right)$ \\
\hline 1 & 17,2 \\
\hline 2 & 16,9 \\
\hline 3 & 16,9 \\
\hline 4 & 16,9 \\
\hline 5 & 16,7 \\
\hline 6 & 16,8 \\
\hline 7 & 16,6 \\
\hline 8 & 16,6 \\
\hline 9 & 16,7 \\
\hline 10 & 16,6 \\
\hline 11 & 16,6 \\
\hline 12 & 16,5 \\
\hline 13 & 16,5 \\
\hline 14 & 16,3 \\
\hline 15 & 16,1 \\
\hline 16 & 16,0 \\
\hline 17 & 16,0 \\
\hline 18 & 15,9 \\
\hline 19 & 15,8 \\
\hline 20 & 15,7 \\
\hline
\end{tabular}

Hasil yang didapat pada pengujian ketiga pada $200 \mathrm{~mL}$ air perubahan suhu yang didapat yaitu mencapai $1,5^{\circ} \mathrm{C}$ dengan suhu awal pada menit pertama pembacaan thermokopel yaitu $17,2^{\circ} \mathrm{C}$ dan penurunan suhu pada pembacaan akhir pengujian termokopel yaitu mencapai $15,7^{\circ} \mathrm{C}$ pada penurunan suhu yang dipengaruhi oleh beban $200 \mathrm{~mL}$ air dikarenakan semakin besar beban yang didinginkan maka semakin besar pula kalor yang dipindahkan oleh petier. 
Berikut ini adalah kurva pengujian suhu terhadap waktu pada gambar 6.

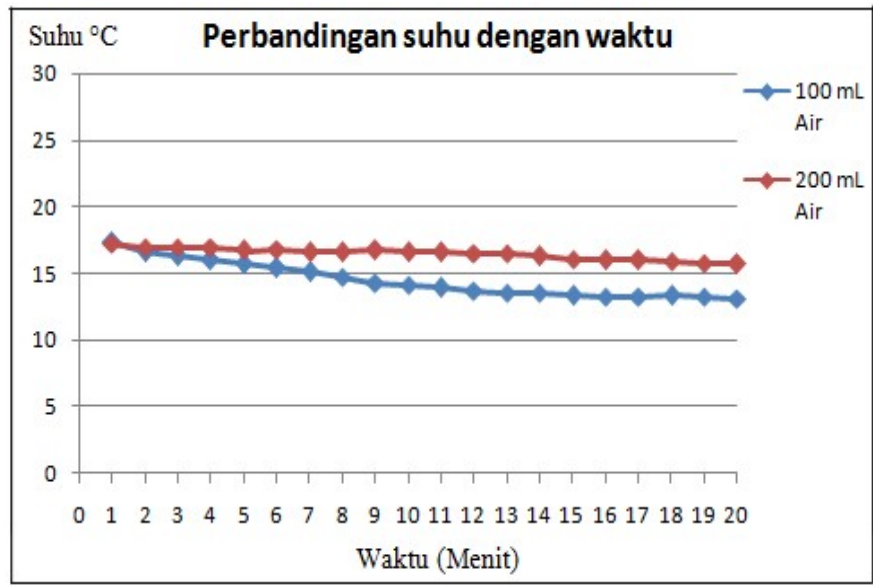

Gambar 6. Kurva Pengujian Suhu Terhadap Waktu

Pada gambar 6 menunjukan kurva pengujian terhadap lemari pendingin pada volume $100 \mathrm{~mL}$ dan $200 \mathrm{~mL}$ air pada penurunan suhu awal terdapat penurunan selisih suhu $0,1^{\circ} \mathrm{C}$ yang dipengaruhi oleh beban yang lebih besar yaitu dengan $200 \mathrm{~mL}$ air dengan penurunan suhu pada menit pertama, pada menit ke 12 dan menit ke 13 terjadi penunjukan suhu yang berbeda pada $200 \mathrm{ml}$ air dan $100 \mathrm{~mL}$ air yang dipengaruhi oleh perubahan pada temperatur suhu ruangan yang tidak konstan yang dihisap oleh kipas pendingin untuk membantu pembuangan kalor dari sisi panas peltier. Pada suhu akhir terdapat perbedaan yang dipengaruhi oleh perbedaan temperatur pada pada suhu yang terdapat pada ruangan disaat menit ke 2 dan menit ke 3 pada $100 \mathrm{~mL}$ air dan $200 \mathrm{~mL}$ air.

\subsection{Pembahasan}

Hasil pengujian menunjukan bahwa hal yang mempengaruhi penurunan temperature dalam pengaruh peltier atau TEC (Thermo Electric Cooler) adalah pengaruh terhadap temperature suhu pada ruangan atau lingkungan sekitar dan kontinyu alat bekerja [8]. Dalam proses pendinginan pada media air untuk mempercepat proses pendinginan perlu memperhatikan dari temperatur suhu ruangan atau lingkungan sekitar karena mempengaruhi dari proses pembuangan kalor yang dihasilkan oleh bagian sisi panas dari peltier yang harus dibuang untuk memberikan efek yang dingin pada bagian sisi dingin, karena peltier memiliki dua sisi yaitu sisi dingin dan sisi panas [9]. Pada bagian sisi panas peltier menghasilkan kalor yang dapat mempengaruhi mempengaruhi sisi dari bagian yang dingin dari peltier dengan selisih suhu pada sisi dingin dan sisi panas yaitu mencapai $30{ }^{\circ} \mathrm{C}$ pada kedua sisi keramik peltier [10][11].

Panas jenis yang merupakan Energi yang dibutuhkan untuk kenaikan suhu sebesar 1 derajat celcius untuk setiap $1 \mathrm{~kg}$ berat materialnya. Sebagai contoh kalor jenis air $4190 \mathrm{Joule} /\left(\mathrm{kg}{ }^{\circ} \mathrm{C}\right)$ artinya, $1 \mathrm{~kg}$ air butuh Energi 4190 Joule supaya suhunya naik sebesar $1{ }^{\circ} \mathrm{C}$ atau sebaliknya. Air seberat $1 \mathrm{~kg}$ suhunya akan turun $1{ }^{\circ} \mathrm{C}$ jika Energinya diambil sebesar 4190 Joule. Sama seperti air, udara juga memiliki kalor jenis.

Dengan rumus:

$$
\mathrm{Q}=m, c p, \Delta T
$$

Keterangan Rumus :

$\mathrm{Q}=$ Banyak kalor yang diserap atau dilepaskan Energi kalor (Joule)

$\mathrm{cp}=$ Kalor jenis (kalor jenis udara : $1000 \mathrm{Joule} /\left(\mathrm{kg}{ }^{\circ} \mathrm{C}\right)$

$\mathrm{m}=$ Volume $\mathrm{x}$ massa jenis (massa jenis udara $: 1.2 \mathrm{~kg} / \mathrm{m}^{3}$ )

$\Delta T=$ Perbedaan suhu (suhu awal - suhu akhir) $\left({ }^{\circ} \mathrm{C}\right)$

Daya listrik yang diberikan pada elemen peltier (watt)

Dengan rumus: 


$$
\mathrm{P}_{\text {in }}=\mathrm{V} \times \mathrm{I}_{\mathrm{Total}}
$$

Keterangan Rumus :

$\mathrm{P}_{\mathrm{in}}=$ Daya listrik yang diberikan pada rangkaian (Watt)

$\mathrm{V}=$ Tegangan suplai pada komponen peltier dan komponen pendukung lainya (Volt)

$\mathrm{I}_{\text {Total }}=$ Arus yang dibutuhkan untuk keseluruhan pada rangkaian instalasi pada pendingin (Ampere)

Dalam aplikasi dari pendingin TEC, COP (Coefficient Of Performance) adalah koefisien rasio pemanasan atau pendiginan yang disediakan untuk kebutuhan kerja pada peltier. Jika daya listrik, $\mathrm{P}$, disuplai untuk mencapai kapasitas pendinginan $\mathrm{Q}_{c o o l}$, maka nilai COP adalah sebagai berikut dengan rumus :

$\mathrm{COP}=\frac{\mathrm{Q}}{\mathrm{P}_{\text {in }}}$

Keterangan rumus :

$\mathrm{COP}=$ Koeffesien dari rasio pemanasan atau pendingin yang disediakan untuk kebutuhan kerja pada peltier

$\mathrm{Q} \quad=$ Banyak kalor yang diserap atau dilepaskan Energi kalor (Joule)

$\mathrm{P}_{\text {in }}=$ Daya listrik yang diberikan pada rangkaian (Watt)

\section{Contoh Pengujian Pertama Pada $100 \mathrm{~mL}$ Air}

a. Volume air $=100 \mathrm{~mL}=0,1$ Liter

b. Kalor jenis zat udara $=1000 \mathrm{Joule} /\left(\mathrm{kg}{ }^{\circ} \mathrm{C}\right)$

c. Suhu awal pada display pembacaan termokopel $=34,3{ }^{\circ} \mathrm{C}$.

d. Suhu akhir yang didapat pada display pembacaan termokopel $=20,0{ }^{\circ} \mathrm{C}$.

e. Banyak kalor yang diserap atau dilepaskan oleh Energi kalor (Joule) pada volume air $100 \mathrm{~mL}$ air $\mathrm{Q}=m \cdot c p \cdot \Delta T$

Pada volume air $100 \mathrm{~mL}$ :

$\mathrm{Q}=\left(0,1 \mathrm{~L} \times 1.2 \mathrm{~kg} / \mathrm{m}^{3}\right) \times 1000 \mathrm{Joule} /\left(\mathrm{kg}{ }^{\circ} \mathrm{C}\right) \times 14,3{ }^{\circ} \mathrm{C}$

$\mathrm{Q}=1716$ Joule $=411,8$ Kalori

$1 \mathrm{Kal}=4,2$ Joule

1 Joule $=0,24 \mathrm{Kal}$

Maka,

1716 Joule $\times 0,24 \mathrm{Kal}=\mathbf{4 1 1 , 8} \mathbf{K a l}$

Pada pengujian pertama terdapat 411,8 kalor yang dapat dilepaskan oleh sisi bagian panas pada komponen peltier.

f. Daya yang diberikan pada komponen

$\mathrm{P}_{\text {in }}=\mathrm{V} \times \mathrm{I}_{\text {Total }}$

(6)

$\mathrm{P}_{\text {in }}=12$ Volt $\times 12,82$ Ampere $=153,84$ Watt $\sim 154$ Watt

g. COP (Coefficient Of Performance) dari peltier pada $100 \mathrm{~mL}$ air [7]

$\mathrm{COP}=\frac{\mathbf{Q}}{\mathrm{P}_{\text {in }}}$ 


$$
\mathrm{COP}=\frac{1716 \text { Joule }}{154 \text { Watt }}=\mathbf{1 1 , 1 4}
$$

Adapun tabel yang menunjukan perbandingan hasil pengujian, dari pengujian yang pertama hingga pengujian ketiga pada volume air $100 \mathrm{~mL}$ dan $200 \mathrm{~mL}$ pada penurunan temperature air selama 20 menit pendinginan seperti yang ada pada tabel 6 dan 7 berikut.

Tabel 6. Hasil pengujian volume air $100 \mathrm{~mL}$ dari pertama hingga ketiga

\begin{tabular}{lccc}
\hline Pengujian & Waktu & $\begin{array}{c}\text { Suhu awal pada } \\
\mathbf{1 0 0} \mathbf{~ m L} \text { air }\end{array}$ & $\begin{array}{c}\text { Suhu akhir } \\
\text { pada } \mathbf{1 0 0} \mathbf{~ m L} \text { air }\end{array}$ \\
\hline Pertama & $\begin{array}{c}20 \\
\text { Menit }\end{array}$ & $31,5^{\circ} \mathrm{C}$ & $29,9^{\circ} \mathrm{C}$ \\
Kedua & 20 & $32,8^{\circ} \mathrm{C}$ & $29,3{ }^{\circ} \mathrm{C}$ \\
Ketiga & Menit & & \\
& 20 & $30,8^{\circ} \mathrm{C}$ & $29,0^{\circ} \mathrm{C}$ \\
& Menit & & \\
\hline
\end{tabular}

Tabel 7. Hasil pengujian volume air $200 \mathrm{~mL}$ dari pertama hingga ketiga

\begin{tabular}{lccc}
\hline Pengujian & Waktu & $\begin{array}{c}\text { Suhu awal pada 200 } \\
\text { mL air }\end{array}$ & $\begin{array}{c}\text { Suhu akhir pada } \\
\mathbf{2 0 0} \mathbf{~ m L} \text { air }\end{array}$ \\
\hline Pertama & 20 & $31,8{ }^{\circ} \mathrm{C}$ & $28,8{ }^{\circ} \mathrm{C}$ \\
& Menit & & \\
Kedua & 20 & $31,9{ }^{\circ} \mathrm{C}$ & $28,3{ }^{\circ} \mathrm{C}$ \\
\multirow{2}{*}{ Ketiga } & Menit & & \\
& 20 & $31,1{ }^{\circ} \mathrm{C}$ & $29,2{ }^{\circ} \mathrm{C}$ \\
& Menit & & \\
\hline
\end{tabular}

Dari tabel 7 dan tabel 8 hasil pengujian dari perbandingan volume air $100 \mathrm{~mL}$ dan $200 \mathrm{~mL}$ dari pertama hingga ketiga terhadap penurunan temperature suhu air, dapat menghitung hasil presentasi penurunan selama 20 menit pendinginan dengan asumsi presentasi berikut.

Hasil Penurunan Suhu $=\mathrm{Suhu}_{\mathrm{Awal}}-\mathrm{Suhu}_{\mathrm{Akhir}}$

Presentasi $=\quad \frac{\text { Hasil Penurunan Suhu }}{\text { Suhu awal }} \times 100 \%$

Adapun gambar 7 berikut menujukan perbandingan presentasi dari hasil pendinginan dari pengujian pertama hingga pengujian ketiga dengan volume air $100 \mathrm{~mL}$ dan $200 \mathrm{~mL}$.

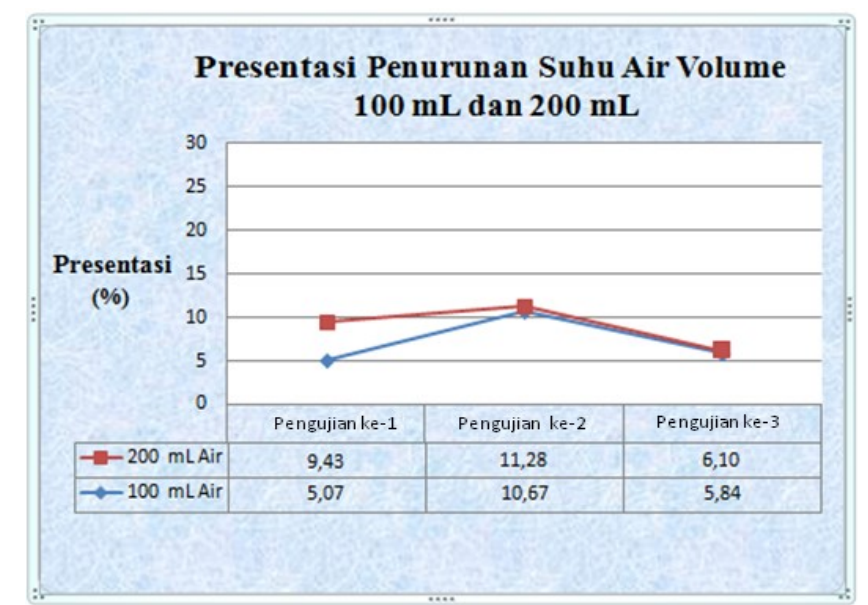

Gambar 7. Grafik Perbandingan Presentasi Volume Air $100 \mathrm{~mL}$ dan $200 \mathrm{~mL}$ 
Pada gambar 7 menunjukan perbandingan pengujian pertama hingga pengujian ketiga dengan penurunan suhu pada volume air $100 \mathrm{~mL}$ dan $200 \mathrm{~mL}$, pada pengujian ke 1 dengan volume $100 \mathrm{~mL}$ presentasi penurunan suhu air sebesar 5,07 \% dan pada $200 \mathrm{~mL}$ presentasi penurunan suhu air sebesar 9,43\%, dan pada pengujian ke 2 dengan volume $100 \mathrm{~mL}$ presentasi penurunan air sebesar 10,67\% dan pada $200 \mathrm{~mL}$ presentasi penurunan suhu air sebesar 11,28\%, dan pada pengujian ke 3 dengan volume $100 \mathrm{~mL}$ presentasi penurunan air sebesar 5,84\% dan pada $200 \mathrm{~mL}$ presentasi penurunan suhu air yaitu sebesar $6,10 \%$.

Dari hasil pengujian tersebut didapatkan hasil rata-rata data yang diperoleh bahwa pada penurunan temperatur, untuk pengujian pertama dengan volume $100 \mathrm{~mL}$ air yaitu $2,3^{\circ} \mathrm{C}$ dan $2,8^{\circ} \mathrm{C}$ pada $200 \mathrm{~mL}$ air dan dengan persentase penurunan suhu mencapai $7,19 \%$ pada $100 \mathrm{~mL}$ air dan $8,93 \%$ volume $200 \mathrm{~mL}$ air.

\section{KESIMPULAN}

Dari hasil pengujian sebanyak tiga kali pada volume air yang berbeda dalam 20 menit pada setiap pengujian hasil data yang diperoleh bahwa pada penurunan temperature pada pengujian pertama dengan volume $100 \mathrm{~mL}$ air yaitu $1,6^{\circ} \mathrm{C}$ dan $3^{\circ} \mathrm{C}$ pada $200 \mathrm{~mL}$ air dan dengan persentase penurunan suhu mencapai $5,07 \%$ pada $100 \mathrm{~mL}$ air dan $9,43 \%$ volume $200 \mathrm{~mL}$ air, pada pengujian kedua dengan volume $100 \mathrm{~mL}$ air yaitu $3,5^{\circ} \mathrm{C}$ dan $3,6^{\circ} \mathrm{C}$ pada $200 \mathrm{~mL}$ air dan dengan persentase penurunan suhu mencapai $10,67 \%$ pada $100 \mathrm{~mL}$ air dan $11,28 \%$ volume $200 \mathrm{~mL}$ air, pada pengujian ketiga dengan volume $100 \mathrm{~mL}$ air yaitu $1,8^{\circ} \mathrm{C}$ dan $1,9^{\circ} \mathrm{C}$ pada $200 \mathrm{~mL}$ air dan dengan persentase penurunan suhu mencapai $5,84 \%$ pada $100 \mathrm{~mL}$ air dan $6,10 \%$ pada $200 \mathrm{~mL}$ air.

\section{DAFTAR PUSTAKA}

[1] Iwan Sumirat, Romanto. 2013. Rancang Bangun Prototipe Kulkas Mini Thermo Electrik.Universitas Ibn Khaldun. Bogor, JuTeks Vol.1 (2) 2014 : (32-38)

[2] Joko subroto, Azridjal Aziz. 2014. Aplikasi modul pendingin thermoelektrik sebagai media pendingin kotak minuman. Universitas Riau. Pekanbaru

[3] Imamduddin, M. Kaisar. 2008. Desain cool box dengan Pompa Kalor Peltier. Seminar Nasional Tahunan Teknik Mesin, SNTTM-VI, 2007 Jurusan Teknik Mesin, Universitas Syiah Kuala p.111118

[4] Roj, Robin, Nils Katenbrink. Investigation on the Application of Different Air-CoolingSystems in a Thermoelectric Setup. Materials Today: Proceedings 2 ( 2015 )p. 714 - 720

[5] Y. Meqorry, P. Wilka, Derisma. Rancang Bangun Sistem Kontrol Temperatur untuk Proses Pendinginan Menggunakan Termoelektrik. Prosiding bidang Fisika Semirata 2015 Bidang MIPA BKS-PTN Barat Universitas Tanjungpura Pontianak (2015), p. 194-203

[6] Gandhi, Frima dan Yusfi, Meqorry. Perancangan Sistem Pendingin Air Menggunakan Elemen Peltier Berbasis Mikrokontroler ATmega8535, Jurnal Fisika Unand Vol. 5, No. 1 (2016), p.35-41.

[7] Terang UHSG, 2016. Analisa kinerja Sistem Pendingin Peltier yang Menggunakan Sel PV dengan Sumber Energi Radiasi Matahari, Jurnal Energi dan Manufaktur Vol. 9 No. 2, Oktober 2016 : (166173).

[8] HAA, Fikri, 2016. Efektifitas Modul Peltier TEC-12706 sebagai Generator dengan Memanfaatkan Energi Panas dari Modul Peltier TEC-12706, Skripsi Teknik Elektro, Universitas Muhammadiyah Surakarta.

[9] Yusfi, 2017. Analisa Pemanfaatan Dua Elemen Peltier pada Pengontrolan Temperatur Air, Spektra: Jurnal Fisika dan Aplikasinya, Vol. 2 (1) : (9-14)

[10] MF. Syukrillah, 2016. Pengujian Mesin Pendingin Minuman Portable menggunakan Port USB dan Adaptor, Jom FTEKNIK Vol.3 (2) 2016 : (1-5)

[11] KH Ardhiaa, 2017. Studi Efektifitas Couple Thermoelektrik sebagai Pendingin Prosesor CITEE 2017, p.137-141 